\title{
PENGAMANAN FILE DOKUMEN MENGGUNAKAN KOMBINASI METODE SUBTITUSI DAN VIGENERE CIPHER
}

\author{
Sarwo Budi ${ }^{1}$, Arif Budimansyah Purba ${ }^{2}$, Jajang Mulyana ${ }^{3}$ \\ ${ }^{1}$ sarwobudi58@gmail.com, 2arifbudimansyahpurba@gmail.com, 3ja2ngm@gmail.com \\ 1,2,3 STMIK Kharisma Karawang
}

\begin{abstract}
Abstrak
Kriptografi adalah metode pengamanan data menggunakan algoritma yang banyak dikembangkan secara berkelanjutan hingga sekarang, kriptografi menawarkan keamanan berupa kerahasiaan data, misalnya kerahasiaan data yang dihasilkan melalui algoritma enkripsi yang mengacak informasi pribadi sehingga tidak dapat terbaca maupun dipecahkan oleh pihak yang tidak berkepentingan. Salah satunya adalah algoritma subtitusi dan vigenere cipher merupakan metode klasik yang digunakan untuk pengamanan data. Kombinasi metode algoritma tersebut menjadi solusi untuk keamanan ganda sebagai proteksi file, Dengan menggunakan aplikasi kriptografi pengamanan data kombinasi algoritma dua metode tersebut menghasilkan file data yang memberikan keamanan lebih pada file teks sehingga tidak mudah dan sulit untuk dipecahkan.
\end{abstract}

Kata kunci: Kriptografi, Subtitusi, Vigenere cipher, SDLC Waterfall

\begin{abstract}
Cryptography is a method of securing data using algorithms that have been developed continuously until now. Cryptography offers security in the form of data confidentiality, for example the confidentiality of data generated through encryption algorithms that scrambles personal information so that it cannot be read or solved by unauthorized parties. One of them is the substitution algorithm and the vigenere cipher is a classic method used for data security. The combination of these algorithm methods becomes a solution for double security as file protection. By using a cryptographic application for data security, the combination of the two method algorithms produces a data file that provides more security to the text file so that it is not easy and difficult to solve.
\end{abstract}

Keywords: Cryptography, Subtitution, Vigenere cipher, SDLC Waterfall

\section{Pendahuluan}

Kemajuan teknologi internet, media digital seperti gambar, audio, video dan file teks dapat dibagi dan dikirimkan melalui Internet dengan lebih mudah dengan bermacam media. Salah satu tantangan utama dalam berbagi dan mentransmisikan semua jenis informasi melalui saluran publik adalah keamanan data [1]. Muncul kebutuhan untuk melindungi informasi yang akan dikirimkan dari penyadap dan pihak yang tidak berwenang. Proses dalam melindungi suatu informasi tersebut dapat dilakukan dengan ilmu atau teknik menyembunyikan pesan dengan suatu cara tertentu sehingga selain si pengirim dan si penerima, tidak ada orang lain yang mengetahui atau menyadari adanya suatu pesan rahasia. Kriptografi adalah ilmu yang mempelajari teknik-teknik matematika yang berhubungan dengan aspek keamanan informasi seperti kerahasiaan, integritas data, serta otentikasi [2].

Kriptografi adalah ilmu yang mempelajari teknik-teknik matematika yang berhubungan dengan aspek keamanan informasi seperti kerahasiaan, integritas data, serta otentikasi [3]. Metode kriptografi adalah alat untuk menawarkan keamanan data. Kriptografi menyediakan fitur seperti kerahasiaan, keaslian, dan integritas data. Misalnya, kerahasiaan data dihasilkan melalui algoritma enkripsi yang mengacak/mencampur informasi pribadi sehingga menjadi tidak dapat dibaca oleh pihak selain penerima yang dimaksud [4]. Enkripsi merupakan proses konversi data dari data biasa menjadi data baru yang disandikan, sedangkan deskripsi yaitu proses pengembalian data yang sudah disandikan menjadi data semula atau data asli [5]. Salah satu metode kriptografi adalah Vigener chiper yang merupakan metode untuk proses membuat kata sandi dari sebuah teks berdasarkan huruf-huruf pada kata kunci deretan sandi Caesar [6] dan sandi Vigenère sebenarnya merupakan pengembangan dari sandi Caesar. Pada sandi Caesar, setiap huruf teks terang digantikan dengan huruf lain yang memiliki perbedaan tertentu pada urutan alfabet. Misalnya pada sandi Caesar dengan geseran 3, A menjadi D, $B$ menjadi $E$ and dan seterusnya. Sandi Vigenère terdiri dari beberapa sandi Caesar dengan nilai geseran yang berbeda [7].

Metode ini tidak menjamin data akan aman apabila mendapatkan dengan jenis serangan brute force attack, maka perlu adanya proteksi keamanan lebih untuk keamanan data tersebut yaitu 
menggunakan metode Subtitusi. Metode substitusi merupakan proses dimana sebuah data diubah menjadi data baru yang bersifat acak [8][9]. Tahap pertama pesan yang disisipkan akan disandikan dengan algoritma substitusi. Untuk mengacak pesan menggunakan algoritma substitusi dimana proses enkripsi tersebut akan sama dilakukan menggunakan perhitungan enkripsi substitusi sampai karakter terakhir. Kemudian dilanjutkan dengan tahap kedua yaitu pengacakan menggunakan algoritma vigenere cipher. Selanjutnya vigenere cipher menggabungkan plaintext (ciphertext-1) dengan kunci sehingga menghasilkan ciphertext yang baru (ciphertext-2).

Dalam penelitian ini pengamanan data menggunakan penggabungan dua metode kriptogafi, dapat menghasilkan keamanan data yang lebih maksimal untuk proteksi data. Untuk perancangan sistem dalam penelitian ini menggunakan metode System Development Life Cycle (SDLC) Waterfall [10]. Dengan menggunakan dua metode kriptografi sebagai pengamanan data, maka diharapkan hal ini dapat menjadi solusi terhadap serangan kriptanalisis. Berdasarkan hal ini maka penelitian ini akan melakukan pengamanan file dokumen menggunakan kombinasi metode subtitusi dan vigenere cipher.

\section{Metode}

Untuk membangun aplikasi Kriptografi Pengamanan data menggunakan penggabungan metode subtitusi dam vigenere cipher ini menggunakan metode SDLC Waterfall dimana dalam penelitian ini hanya akan digunakan empat tahapan dari kelima tahapan pada metode SDLC Waterfall yaitu tahap perencanaan projek, tahap analisis, tahap perancangan dan tahap implementasi. Tahapan SDLC Waterfall adalah sebagai berikut:

\section{Tahap Perencanaan Projek}

Pada tahapan ini dilakukan penelitian terlebih dahulu untuk menyaring data serta informasi yang terkait. Teknik pengumpulan data yang dilakukan adalah dengan melakukan studi literatur/pustaka baik melalui buku ataupun jurnal dan wawancara terhadap bagian pelayanan terkait. Pada tahapan ini, terdapat beberapa aktifitas yang harus dilakukan,diantaranya: Definisikan Masalah, Pengumpulan Data, Menganalisis Teori, Pembuatan Jadwal, Mencari Solusi dan Mendefinisikan kebutuhan.

\section{Tahap Analisis}

1. Analisis Proses

Analisis gabungan kriptografi digambarkan dengan skema pada Gambar 1.

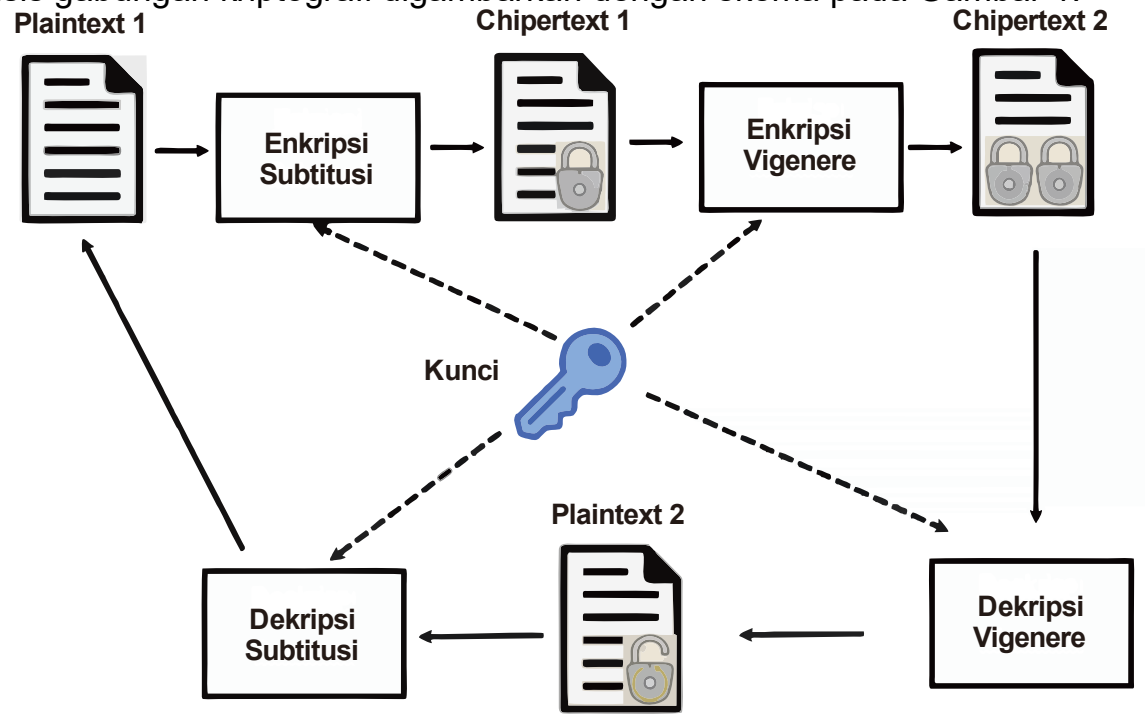

Gambar 1. Skema kombinasi metode subtitusi dan vigenere kriptografi

Proses enkripsi terdiri dari sebuah algoritme dan sebuah kunci dengan nilai yang terlepas dari pesan asli (plaintext) dan mengontrol algoritme yang dipakai. Penerapan algoritme akan menghasilkan output yang berbeda sesuai dengan kunci yang digunakan. Mengubah kunci berarti mengubah output dari algoritme yang dipakai. Setelah chipertext dihasilkan, chipertext tersebut dapat diubah kembali menjadi pesan asli dengan algoritme dekripsi dan dengan kunci yang sama seperti yang digunakan pada saat enkripsi [11][12]. 


\section{Analisis Sistem}

Analisis sistem aplikasi kriptografi menggunakan Object Oriented Analysis (OOA) yaitu :

1. System Activities (Actor Description and Use Case Description, Use Case Diagram, Scenario Use Case).

2. Class Diagram (Class Definition, Class Relation).

3. Object Interaction (Sequence Diagram).

4. Object Behavior (Activity Diagram).

\section{Tahap Perancangan}

Tahapan perancangan yang dilakukan oleh peneliti adalah desain berbasis Object Oriented Design (OOD) yang terdiri dari :

1. Desain Proses

Rancangan logika pemrosesan data yang akan disajikan menggunakan flowchart dalam menggambarkan urutan pada aplikasi ini [13].

Berikut Gambar 2. diagram flowchart proses kriptografi dengan dua metode :
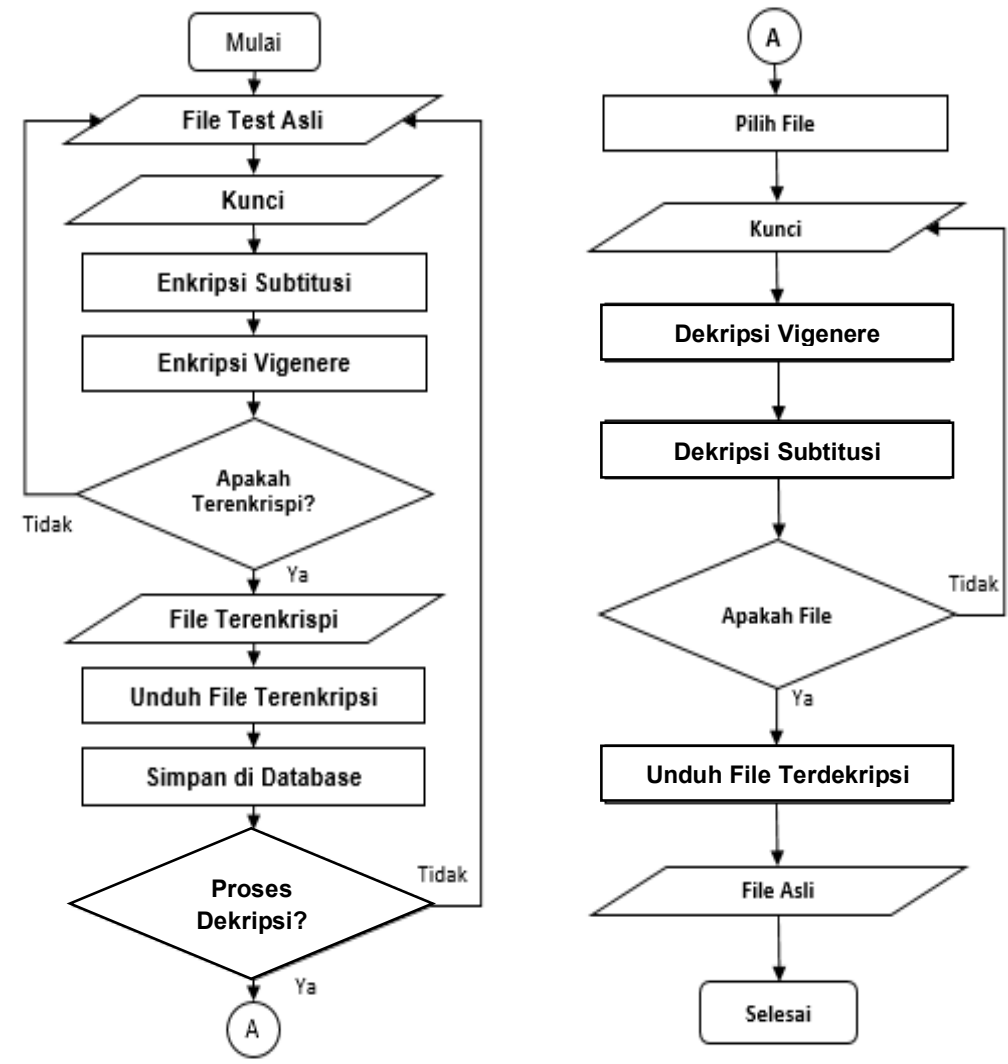

2. Desain Antarmuka

Gambar 2. Flowchart Kriptografi

Aplikasi biasanya berupa perangkat lunak yang berbentuk software yang berisi kesatuan perintah atau program yang dibuat untuk melaksanakan sebuah pekerjaan yang diinginkan [14]. Untuk itu diperlukan rancangan tampilan aplikasi yang akan dioperasikan oleh pengguna (user).

\section{Tahap Implementasi}

Tahapan implementasi merupakan tahap pembuatan program termasuk penulisan kode program. Pada Tahapan ini meliputi:

1. Instalasi Sistem

2. Pelatihan Prosedural

3. Pengujian Sistem (pengujian whitebox dan blackbox).

Software testing merupakan sebuah alat yang menjamin kualitas perangkat lunak yang diterapkan untuk mengontrol kualitas produk perangkat lunak sebelum penyerahan atau instalasi ditempat pengguna. Software testing dapat diklasifikasikan berdasarkan konsep pengujian, yaitu black box (fungsional) testing dan whitebox (struktural) testing [15]. 


\section{Hasil dan Pembahasan}

Dalam penelitian kriptografi dengan media pesan file teks format $t x t$ sebagai Plaintext yang di acak dengan algoritma kriptografi substitusi dan vigenere cipher. Pesan teks (plaintext) akan dienkripsi menggunakan algoritma substitusi menghasilkan ciphertext yang akan dienkripsi lagi menggunakan vigenere cipher dengan kunci tertentu menghasilkan ciphertext-2. Hasil dari ciphertext2 dan selanjutnya di simpan di dalam file database.

Sesuai dengan alur diagram flowchart analisis untuk pengamanan file, maka pesan asli akan diacak (enkripsi) terlebih dulu menjadi pesan tersandi (ciphertext). Dengan hasil analisis sebagai berikut :

Pesan asli : STMIK Kharisma 92 (17 karakter).

Kunci : karawang (8 karakter).

Untuk index karakter pesan asli dapat dilihat pada Tabel 1. Index karakter pesan asli berikut:

Tabel 1. Index Karakter Pesan Asli

\begin{tabular}{ccc}
\hline Index ke-i & Pesan asli (P) & Desimal dalam ASCll 128 bit \\
\hline $\mathrm{P}_{1}$ & $\mathrm{~S}$ & 83 \\
$\mathrm{P}_{2}$ & $\mathrm{~T}$ & 84 \\
$\mathrm{P}_{3}$ & $\mathrm{M}$ & 77 \\
$\mathrm{P}_{4}$ & $\mathrm{I}$ & 73 \\
$\mathrm{P}_{5}$ & $\mathrm{~K}$ & 75 \\
$\mathrm{P}_{6}$ & $(\mathrm{spasi})$ & 32 \\
$\mathrm{P}_{7}$ & $\mathrm{~K}$ & 75 \\
$\mathrm{P}_{8}$ & $\mathrm{~h}$ & 104 \\
$\mathrm{P}_{9}$ & $\mathrm{a}$ & 97 \\
$\mathrm{P}_{10}$ & $\mathrm{r}$ & 114 \\
$\mathrm{P}_{11}$ & $\mathrm{i}$ & 105 \\
$\mathrm{P}_{12}$ & $\mathrm{~S}$ & 115 \\
$\mathrm{P}_{13}$ & $\mathrm{~m}$ & 109 \\
$\mathrm{P}_{14}$ & $\mathrm{a}$ & 97 \\
$\mathrm{P}_{15}$ & $(\mathrm{spasi})$ & 32 \\
$\mathrm{P}_{16}$ & 9 & 57 \\
$\mathrm{P}_{17}$ & 2 & 50
\end{tabular}

Untuk index karakter kunci dapat dilihat pada Tabel 2. Index karakter kunci berikut:

Tabel 2. Index Karakter Kunci

\begin{tabular}{ccc}
\hline Index ke-i & Kunci (K) & Desimal dalam ASCII 128 bit \\
\hline $\mathrm{K}_{1}$ & $\mathrm{k}$ & 107 \\
$\mathrm{~K}_{2}$ & $\mathrm{a}$ & 97 \\
$\mathrm{~K}_{3}$ & $\mathrm{r}$ & 114 \\
$\mathrm{~K}_{4}$ & $\mathrm{a}$ & 97 \\
$\mathrm{~K}_{5}$ & $\mathrm{w}$ & 119 \\
$\mathrm{~K}_{6}$ & $\mathrm{a}$ & 97 \\
$\mathrm{~K}_{7}$ & $\mathrm{n}$ & 110 \\
$\mathrm{~K}_{8}$ & $\mathrm{~g}$ & 103 \\
\hline
\end{tabular}


Proses penyisipan pesan sebagai berikut:

\section{Enkripsi Algoritma Substitusi}

Pesan yang disisipkan akan disandikan dengan algoritma substitusi. Untuk mengacak pesan menggunakan algoritma substitusi, perhitungannya sebagai berikut:

$C_{i}=\left(P_{i}+K\right) \bmod 128$

Dimana,

$\begin{array}{ll}\mathrm{C}_{\mathrm{i}} & =\text { Ciphertext ke-i } \\ \mathrm{Pi} & =\text { Plaintext ke-i } \\ \mathrm{K} & =\text { Panjang kunci asli } \\ \text { mod 128 } & =\text { ASCll 128 bit }\end{array}$

Enkripsi Algoritma Substitusi:

Untuk $\mathrm{P}_{1}=\mathrm{S}$, maka:

$$
\begin{aligned}
\mathbf{C}_{1} & =\left(P_{i}+K\right) \bmod 128 \\
& =(83+17) \bmod 128 \\
& =100 \bmod 128 \\
& =100 \\
& =\mathbf{d}(\text { konversi karakter dari ASCII) }
\end{aligned}
$$

Proses enkripsi akan sama dilakukan menggunakan perhitungan enkripsi substitusi sampai karakter terakhir yaitu $P_{17}=2$. Hasil enkripsi dapat dilihat pada Tabel 3 . Hasil enkripsi substitusi berikut:

Tabel 3. Hasil Enkripsi Subtitusi

\begin{tabular}{cccc}
\hline Plaintext (P) & Desimal dalam ASCII 256 bit & $\mathbf{P}_{\mathrm{i}}+\mathbf{N}$ mod 128 & Ciphertext (C) \\
\hline S & 83 & 100 & $\mathrm{~d}$ \\
T & 84 & 101 & $\mathrm{e}$ \\
M & 77 & 100 & $\mathrm{~d}$ \\
I & 73 & 101 & $\mathrm{e}$ \\
K & 75 & 94 & $\wedge$ \\
(spasi) & 32 & 90 & $\mathrm{Z}$ \\
K & 75 & 92 & $\mathrm{I}$ \\
h & 104 & 49 & 1 \\
a & 97 & 92 & $\mathrm{I}$ \\
r & 114 & 121 & $\mathrm{y}$ \\
i & 105 & 114 & $\mathrm{r}$ \\
s & 115 & 3 & (null) \\
m & 109 & 122 & $\mathrm{z}$ \\
a & 97 & 4 & (null) \\
(spasi) & 32 & 126 & $\sim$ \\
9 & 57 & 114 & $\mathrm{r}$ \\
2 & 50 & 49 & 1 \\
\hline
\end{tabular}

Pesan hasil enkripsi substitusi (ciphertext-1) adalah de^Zl1lyr z r1JC.

\section{Enkripsi Algoritma Vigenere Cipher}

Setelah tahap pertama pengacakan pesan akan dilanjutkan dengan tahap kedua yaitu pengacakan menggunakan algoritma vigenere cipher. Vigenere cipher menggabungkan plaintext (ciphertext-1) dengan kunci sehingga menghasilkan ciphertext yang baru (ciphertext-2). Untuk 
mengacak pesan menggunakan perhitungan berikut:

$C_{i}=\left(P_{i}+K_{i}\right) \bmod 128$

Dimana,

$\begin{array}{ll}\mathrm{C}_{\mathrm{i}} & =\text { Ciphertext ke-i } \\ \mathrm{Pi}_{\mathrm{i}} & =\text { Plaintext ke-i } \\ \mathrm{K}_{\mathrm{i}} & =\text { Kunci ke-i } \\ \text { mod 128 } & =\text { ASCII 128 bit }\end{array}$

Enkripsi Vigenere Cipher:

Untuk $\mathrm{P}_{1}=\mathrm{S}$ dan $\mathrm{K}_{1}=\mathrm{k}$, maka:

$\mathbf{C}_{1}=\left(\mathrm{P}_{\mathrm{i}}+\mathrm{K}_{\mathrm{i}}\right) \bmod 128$

$=(100+107) \bmod 128$

$=207 \bmod 128$

$=79$

$=\mathbf{O}$ (konversi karakter dari ASCII)

Proses enkripsi akan sama dilakukan menggunakan perhitungan enkripsi vigenere sampai karakter terakhir yaitu $\mathrm{P}_{17}=2$ dan perulangan kunci $\mathrm{K}_{17}=\mathrm{k}$. Hasil enkripsi dapat dilihat pada Tabel 4. Hasil enkripsi vigenere cipher berikut:

Tabel 4. Hasil Enkripsi Vigenere Cipher

\begin{tabular}{|c|c|c|c|c|c|}
\hline Plaintext (P) & $\begin{array}{c}\text { Desimal dalam } \\
\text { ASCII }\end{array}$ & Kunci (K) & $\begin{array}{c}\text { Desimal dalam } \\
\text { ASCII }\end{array}$ & $\begin{array}{c}P_{i}+K_{i} \bmod \\
128\end{array}$ & Ciphertext (C) \\
\hline$d$ & 100 & $\mathrm{k}$ & 107 & 79 & O \\
\hline e & 101 & a & 97 & 70 & $\mathrm{~F}$ \\
\hline$\wedge$ & 94 & $r$ & 114 & 80 & $\mathrm{P}$ \\
\hline Z & 90 & $\mathrm{a}$ & 97 & 59 & ; \\
\hline 1 & 92 & w & 119 & 83 & $S$ \\
\hline 1 & 49 & a & 97 & 18 & (null) \\
\hline 1 & 92 & $\mathrm{n}$ & 110 & 74 & $\mathrm{~J}$ \\
\hline$y$ & 121 & $g$ & 103 & 96 & 冫 \\
\hline$r$ & 114 & $\mathrm{k}$ & 107 & 93 & ] \\
\hline$f$ & 131 & a & 97 & 100 & $d$ \\
\hline$z$ & 122 & $r$ & 114 & 108 & 1 \\
\hline$"$ & 132 & a & 97 & 101 & e \\
\hline$\sim$ & 126 & w & 119 & 117 & $\mathrm{u}$ \\
\hline$r$ & 114 & $a$ & 97 & 83 & $S$ \\
\hline 1 & 49 & $\mathrm{n}$ & 110 & 31 & (null) \\
\hline $\mathrm{J}$ & 74 & $g$ & 103 & 49 & 1 \\
\hline $\mathrm{C}$ & 67 & $\mathrm{k}$ & 107 & 46 & \\
\hline
\end{tabular}

Pesan hasil enkripsi Vigenere (ciphertext-2) adalah OFP;S J’]dleuS 1.

\section{Dekripsi Algoritma Vigenere}

Setelah tahap pengambilan pesan akan dilanjutkan dengan tahap dekripsi menggunakan algoritma Vigenere cipher. Vigenere cipher ini menggunakan kunci yang sama pada enkripsi yaitu "karawang". Untuk dekripsi pesan menggunakan perhitungan berikut:

$P_{i}=\left(C_{i}+K_{i}\right) \bmod 128$ 


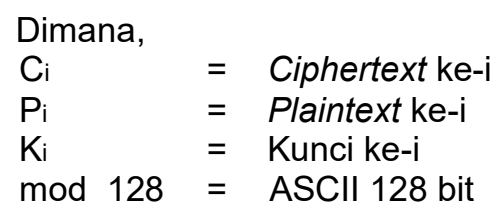

Dekripsi Vigenere Cipher:

Untuk $\mathrm{C}_{1}=\mathrm{O}$ dan $\mathrm{K}_{1}=\mathrm{k}$, maka:

$\mathbf{P}_{1}=\left(\mathrm{C}_{\mathrm{i}}-\mathrm{K}_{\mathrm{i}}\right) \bmod 128$

$=(207-107) \bmod 128$

$=100 \bmod 128$

$=100$

$=\mathbf{d}$ (konversi karakter dari ASCII)

Proses dekripsi akan sama dilakukan menggunakan perhitungan dekripsi vigenere sampai karakter terakhir yaitu $\mathrm{C}_{17}=1$ dan perulangan kunci $\mathrm{K}_{17}=\mathrm{k}$. Hasil dekripsi untuk seluruh karakter dapat dilihat pada Tabel 5. Hasil dekripsi vigenere cipher berikut:

Tabel 5. Hasil Dekripsi Vigenere Cipher

\begin{tabular}{|c|c|c|c|c|c|}
\hline Ciphertext (C) & Desimal dalam ASCII & Kunci (K) & Desimal dalam ASCII & $C_{i}-K_{i} \bmod 128$ & Plaintext $(P)$ \\
\hline 0 & 79 & $\mathrm{k}$ & 107 & 100 & $d$ \\
\hline $\mathrm{F}$ & 70 & $a$ & 97 & 101 & e \\
\hline$P$ & 80 & $r$ & 114 & 94 & $\wedge$ \\
\hline ; & 59 & $a$ & 97 & 90 & z \\
\hline$S$ & 83 & w & 119 & 92 & 1 \\
\hline (null) & 18 & $a$ & 97 & 49 & 1 \\
\hline $\mathrm{J}$ & 74 & $\mathrm{n}$ & 110 & 92 & 1 \\
\hline ' & 96 & $\mathrm{~g}$ & 103 & 121 & $y$ \\
\hline ] & 93 & $\mathrm{k}$ & 107 & 114 & $r$ \\
\hline$d$ & 100 & $a$ & 97 & 3 & (null) \\
\hline I & 108 & $r$ & 114 & 122 & z \\
\hline e & 101 & $a$ & 97 & 4 & (null) \\
\hline u & 117 & w & 119 & 126 & $\sim$ \\
\hline$S$ & 83 & $a$ & 97 & 114 & $r$ \\
\hline (null) & 31 & $\mathrm{n}$ & 110 & 49 & 1 \\
\hline $\begin{array}{l}1 \\
-\end{array}$ & $\begin{array}{l}49 \\
46\end{array}$ & $\begin{array}{l}\mathrm{g} \\
\mathrm{k}\end{array}$ & $\begin{array}{l}103 \\
107\end{array}$ & $\begin{array}{l}74 \\
67\end{array}$ & $\begin{array}{l}\mathrm{J} \\
\mathrm{C}\end{array}$ \\
\hline
\end{tabular}

Pesan hasil dekripsi Vigenere adalah de^Z11lyr z r1JC.

\section{Dekripsi Algoritma Substitusi}

Pesan hasil dekripsi Vigenere akan didekripsikan lagi menggunakan algoritma substitusi untuk memperoleh pesan asli. Untuk dekripsi pesan menggunakan algoritma substitusi, perhitungannya berikut:

$P_{i}=\left(C_{i}-N\right) \bmod 128$

Dimana,
$\mathrm{Ci}_{\mathrm{i}}$
$=$ Ciphertext ke-i
$=$ Plaintext ke- $\mathrm{i}$ 


$$
\begin{array}{ll}
\mathrm{N} & =\text { Panjang pesan } \\
\bmod 128 & =\text { ASCII 128 bit }
\end{array}
$$

Dekripsi algoritma substitusi:

Untuk $\mathrm{P}_{1}=\mathrm{d}$, maka :

$$
\begin{aligned}
\mathbf{P}_{1} & =\left(\mathrm{C}_{i}-\mathrm{N}\right) \bmod 128 \\
& =(100-17) \bmod 128 \\
& =83 \bmod 128 \\
& =83 \\
& =\mathbf{S} \text { (konversi karakter dari ASCII) }
\end{aligned}
$$

Proses dekripsi akan sama dilakukan menggunakan perhitungan dekripsi substitusi sampai karakter terakhir yaitu $\mathrm{C}_{17}=\mathrm{C}$. Hasil dekripsi dapat dilihat pada Tabel 6. Hasil dekripsi substitusi berikut:

Tabel 6. Hasil Dekripsi Subtitusi

\begin{tabular}{cccc} 
Plaintext $(P)$ & Desimal ASCII & $\mathrm{C}_{\mathrm{i}}-\mathrm{N}$ mod 128 & Plaintext $(P)$ \\
\hline $\mathrm{d}$ & 100 & 83 & $\mathrm{~S}$ \\
$\mathrm{e}$ & 101 & 84 & $\mathrm{~T}$ \\
$\wedge$ & 94 & 77 & $\mathrm{M}$ \\
$\mathrm{z}$ & 90 & 73 & $\mathrm{I}$ \\
I & 92 & 75 & $\mathrm{~K}$ \\
1 & 49 & 32 & (spasi) \\
I & 92 & 75 & $\mathrm{~K}$ \\
$\mathrm{y}$ & 121 & 104 & $\mathrm{~h}$ \\
$\mathrm{r}$ & 114 & 97 & $\mathrm{a}$ \\
(null) & 3 & 114 & $\mathrm{i}$ \\
$\mathrm{z}$ & 122 & 105 & $\mathrm{~s}$ \\
(null) & 4 & 115 & $\mathrm{~m}$ \\
$\sim$ & 126 & 109 & $\mathrm{a}$ \\
$\mathrm{r}$ & 114 & 97 & $(\mathrm{spasi})$ \\
1 & 49 & 32 & 9 \\
$\mathrm{~J}$ & 74 & 57 & 2 \\
C & 67 & 50 & \\
\hline
\end{tabular}

Pesan hasil dekripsi substitusi adalah STMIK Kharisma 92.

\section{Kesimpulan dan Saran}

Berdasarkan hasil penelitian dan pembahasan yang dilakukan maka diperoleh kesimpulan bahwa aplikasi kriptografi ini dapat diimplementasikan pada software database MySQL menggunakan sistem operasi linux maupun sistem operasi berlisensi sebagai keamanan data file dokumen dengan metode kombinasi algoritma substitusi dan vigenere cipher ini menghasilkan file yang terenkrip atau rahasia dalam format file txt yang secara kualitas tidak berbeda dan memiliki ukuran yang sama dari ukuran file text awal. Untuk pengembangan aplikasi ini disarankan agar media kriptografi dapat berupa multimedia seperti keamanan data file yang berisi gambar dan format file text yang bervariasi seperti format odt, docx atau format yang lain. Pesan yang dienkripsi maupun di deskripsi tidak hanya berupa file teks, dapat dikembangkan dengan pesan suara, gambar atau multimedia lain.

\section{Daftar Pustaka}

[1] Widianto, Septian Rheno. Desain Algoritma Steganografi dengan Metode Spread Spectrum Berbasis PCMK (Permutasi Chaotic Multiptaran Mengecil dan Membesar) Yang Tahan Terhadap Gangguan. Prodi Teknologi Rekayasa Perangkat Lunak Politeknik Enjinering Indorama Kembang Kuning Ubrug Jatiluhur, Purwakarta. p- ISSN: 2407 - 184 e ISSN: 2460 -8416, 2018. 
[2] Irawan, Muhammad Dedi., Implementasi Kriptografi Vigenere Chiper Dengan PHP. Program Studi Teknik Informatika. Universitas Asahan. Jurnal Teknologi Informasi (JurTI) Volume 1, Nomor 1, P-ISSN 2580-7927. 2017

[3] Sa'id, Fauzus., Wijanarto. Implementasi Algoritma Vigenere dan Metode LSBMR Pada Citra Diam. Teknik Informatika, Fakultas Ilmu Komputer, Universitas Dian Nuswantoro. Techno.COM, Vol. 14, No. 3: 189-197. Agustus 2015.

[4] Rohmanu, Ajar. Implementasi Kriptografi dan Steganografi Dengan Metode Algoritma Des dan Metode End of File. Teknik Informatika, STMIK Cikarang. Jurnal Informatika SIMANTIK Vol.1 No.2 ISSN: 2541-3244. Maret 2017.

[5] Maesyaroh, Siti.. Enkripsi Data dengan Menggunakan Metode Subtitusi. Program Studi Teknik Informatika Fakultas IImu Komputer Universitas Kuningan (UNIKU). Jurnal Buffer Informatika, Volume 3 Nomor 1, ISSN 2527-4856. 2017

[6] M. Azman Maricar dan Nyoman Putra Sastra. Efektivitas Pesan Teks dengan Cipher Substitusi, Vigenere Cipher, dan Cipher Transposisi. Majalah IImiah Teknologi Elektro, Vol. 17, No. 1,Januari -April 2018. p- ISSN:1693 - 2951; e-ISSN: 2503-2372. 2018

[7] Efrandi, Asnawati, Yupiyanti. Aplikasi Kriptografi Pesan Menggunakan Algoritma Vigenere Chiper. Program Studi Teknik Informatika Fakultas IImu Komputer Universitas Dehasen Bengkulu. Jurnal Media Infotama Vol. 10 No. 2, ISSN 1858 - 2680, September 2014.

[8] Hernawandra, Priyagung., Supriyadi, Lenggana, U. Tresna. Aplikasi Steganografi Menggunakan LSB 4 Bit Sisipan dengan Kombinasi Algoritma Substitusi dan Vigenere Berbasis Android. Program Studi Informatika, STMIK Kharisma Karawang. Jurnal Teknologi dan Sistem Komputer, 6(2, 44-50. E-ISSN:2338-0403, 2018

[9] Setiadi, et al, Kombinasi Chiper Subtitusi (Beaufort Dan Vigenere) Pada Citra Digital. Program Studi Teknik Informatika, Fakultas IImu Komputer, Universitas Dian Nuswantoro Semarang. Prosiding SENDI_U. ISBN: 978-979-3649-99-3. 2018

[10] Satzinger, John W., Jackson, Robert B., Burd, Stephen D. System Analysis and Design in a Changing World, Fourth Edition, Thomson Course Technology. Canada. ISBN-13: 9781423902287, ISBN- 10: 1-4239-0228-9. 2010.

[11] Albert Ginting, R. Rizal Isnanto, Ike Pertiwi Windasari., Implementasi Algoritma Kriptografi RSA untuk Enkripsi dan Dekripsi Email. Program Studi Sistem Komputer Fakultas Teknik Universitas Diponegoro. Semarang. Jurnal Teknologi dan Sistem Komputer, Vol 3, No. 2, April. e-ISSN: 2338-0403. 2015

[12] Ebook Teori dan Aplikasi Kriptografi.Sentot Kromodimoeljo Desember 2009.ISBN 978-60296233-0-7. Penerbit SPK IT Consulting. 2009 SPK IT Consulting.

[13] Anwar, et al, Implementasi Kriptografi Dengan Enkripsi Shift Vigenere Chiper Serta Checksum Menggunakan CRC32 Pada Data Text. Jurusan Magister Ilmu Komputer, Universitas Budi Luhur. Jurnal Sistem Informasi Volume.2, ISSN: 2406-7768. 2015

[14] Rojali Soni Afandi dan Erik Hadi Saputra., Aplikasi Mobile Informasi Kafe 24 Jam Di Yogyakarta Berbasis Android., Jurnal IImiah DASI Vol. 14 No. 04, pp: ISSN: 1411-3201. Desember 2013.

[15] Galin, Daniel. Software Quality Assurance from Theory to Implementation. England, AddisonWesley. ISBN 020170945 7. 2004. 